\title{
Long-Term Investigation of Regional Topographic Effects on Soil Chemical Properties and Heavy Metal Concentrations in Paddy Fields
}

\author{
Byung-Koo Ahn, Seong-Soo Kang', Jae-Yeon Shin $^{2}$, and Jin-Ho Lee ${ }^{2} *$ \\ Jeollabuk-do Agricultural Research and Extension Services, Iksan 570-704, Korea \\ ${ }^{1}$ National Academy of Agricultural Science, RDA, Suwon 441-707, Korea \\ ${ }^{2}$ Department of Bioenvironmental Chemistry, Chonbuk National University, Jeonju 561-756, Korea
}

\begin{abstract}
Topographic conditions of agricultural fields work as a important factor to identify different soil properties. This study was conducted to investigate the selected soil chemical properties and the concentrations of heavy metals, $\mathrm{Cd}, \mathrm{Cr}, \mathrm{Pb}, \mathrm{Cu}, \mathrm{Ni}$, and $\mathrm{Zn}$, in the paddy fields of different topographic areas at four year intervals from 1999 to 2011. Three-hundred soil sampling sites in the paddy fields were selected from the different topographic areas that were local valley and fans, fluvio-marine deposits, alluvial plains, and diluvial terraces. The mean values of soil $\mathrm{pH}$ ranged $5.7 \sim 5.8$ that were within optimal range for rice cultivation. The mean values of other properties such as soil organic matter (SOM) content, the concentrations of exchangeable cations, $\mathrm{K}^{+}, \mathrm{Ca}^{2+}$, and $\mathrm{Mg}^{2+}$, and available silicate concentration were lower or close to the optimal values, but the mean concentrations of available phosphorus were exceeded the range of optimal value, $80 \sim 120 \mathrm{mg} \mathrm{kg}^{-1}$, in many paddy fields. In particular, The concentrations of available phosphorus in the paddy fields of local valley and fans, alluvial plains, and fluvio-marine plains were mostly declined. However, in diluvial terrace areas, the phosphorus concentrations unexpectedly increased; furthermore, they were significantly higher than those in other topographic areas. The mean concentrations of $0.1 \mathrm{M} \mathrm{HCl}$-extractable heavy metals, $\mathrm{Cd}, \mathrm{Cr}, \mathrm{Pb}$, $\mathrm{Cu}, \mathrm{Ni}$, and $\mathrm{Zn}$, in the paddy fields were slightly and gradually declined during the study years, but the $\mathbf{P b}$ concentrations were not statistically changed. In addition, the concentrations of heavy metals were widely ranged depending on the different sampling sites. Nevertheless, the concentrations of heavy metals were significantly lower than the levels of Soil Contamination Waming Standard (SCWS) for agricultural lands (1-region) presented in Soil Environment Conservation Law (SECL).
\end{abstract}

Key words: Paddy field, Soil chemical property, Heavy metal, Topography

\section{Introduction}

Soils has been greatly influenced by topographic conditions. The topographic condition of an agricultural field in small local areas is one of the most important factors to identify difference of soil properties as comparing with other fields (Jung and Kim, 1988). Thus, topographic-base investigations for soil properties would be very efficient to have valuable information for utilizing and managing the agricultural lands. Topographic distribution of agricultural lands in Korea includes local valley and fans, fluvio-marine deposits, alluvial plains, diluvial terraces, mountain footslopes, hillslopes, mountains, and lava plains. Paddy fields in Korea are mostly located in all the topographic areas,

\footnotetext{
Received : 2012. 8. 20 Accepted : 2012. 9. 12

*Corresponding author : Phone: +82632702545

E-mail: jinholee@jbnu.ac.kr
}

except in hillslopes and mountains (Hyeon et al., 1989) even though the parent materials of soils and the types of soil formation are different.

Areas of agricultural lands in Jeonbuk province, Korea were 209,800 ha, which were $12.0 \%$ of total agricultural lands in Korea. Also, areas of paddy fields in Jeonbuk province were 142,600 ha that were $68.0 \%$ of total agricultural lands in the province (Jeollabuk-Do, 2007). For these reasons, many researches about paddy fields in the province were mostly related to rice productivity with improving soil fertility instead of environmental viewpoint with topographic aspects.

Therefore, objective of this study was to investigate selected soil chemical properties and heavy metal, $\mathrm{Cd}$, $\mathrm{Cr}, \mathrm{Pb}, \mathrm{Cu}, \mathrm{Ni}$, and $\mathrm{Zn}$, concentrations in the paddy fields of different topographic areas. 


\section{Materials and Methods}

This study was conducted from 1999 to 2011 in 14 different counties in Jeonbuk province, Korea. Threehundred soil sampling sites in paddy fields were selected from the different topographic areas that were local valley and fans, fluvio-marine deposits, alluvial plains, and diluvial terraces. Soils were collected from 0 to $15 \mathrm{~cm}$ depth of surface soil in the paddy field during March to April at four year intervals from 1999: 2003, 2007, and 2011. Soil samples were airdried, crushed to pass through a 2-mm sieve and used for determining the selected chemical properties and heavy metal concentrations. The detailed description of soil sampling information was shown in a previous report (Ahn et al., 2012).

The selected chemical properties of soils were determined using the procedures proposed by National Institute of Agricultural Science and Technology (NIAST), Rural Development Association (RDA), Korea $(2000,2010)$. Soil pH was measured using soil-to-water ratio of 1:5 with a $\mathrm{pH}$ meter (Thermo, Orion 3 star). Soil organic matter content was determined by Tyurin titrimetric method. Exchangeable cations were determined by $1.0 \mathrm{M}$ ammonium acetate $\left(\mathrm{CH}_{3} \mathrm{COONH}_{4}\right)$ extraction method. The determining procedures for other soil properties were also presented in a previous report (Ahn et al., 2012).

The concentrations of heavy metals, $\mathrm{Cd}, \mathrm{Cr}, \mathrm{Pb}, \mathrm{Cu}$, $\mathrm{Ni}$, and $\mathrm{Zn}$, in soils of the paddy fields were determined as $0.1 \mathrm{M} \mathrm{HCl}$-extractable metal concentrations.
Ten grams (10 g) of soil samples were weighed and transferred into a $125 \mathrm{~mL}$ conical flask with adding 50 $\mathrm{mL}$ of $0.1 \mathrm{M} \mathrm{HCl}$. The mixture was agitated for 30 min on a reciprocal shaker set at a speed of 180 cycle $\mathrm{min}^{-1}$, and filtered by Advantec Grade No. 6 ashless filter paper to obtain clear extract. The heavy metal concentrations were analyzed using an inductively coupled plasma (ICP) spectrometers (GBC, Integra, Australia).

Pearson correlation analysis (SPSS $12.0 \mathrm{~K}$ ) was used to evaluate the relationship between the parameters related to different results of soil properties and heavy metal contents. Results were evaluated with 95\% confidence intervals, which were presented as $p<0.05$ levels of significance.

\section{Results and Discussion}

The mean values of selected soil chemical properties in the paddy fields determined at four year intervals from 1999 are shown in Table 1. Soil pH values slightly increased until 2007 but decreased in 2011 . However, the changes of soil $\mathrm{pH}$ were within optimal range for rice cultivation. The contents of soil organic matter (SOM) increased from $23 \mathrm{~g} \mathrm{~kg}^{-1}$ in 1999 to 25 $\mathrm{g} \mathrm{kg}^{-1}$ in 2003 but then the SOM contents significantly decreased by $19 \mathrm{~g} \mathrm{~kg}^{-1}$ in 2007 because during the second interval period, rice straw in most paddy fields were removed to use in livestock feed. The concentrations of available phosphorus were only reduced from $135 \mathrm{mg} \mathrm{kg}^{-1}$ down to $108 \mathrm{mg} \mathrm{kg}^{-1}$ in

Table 1. Mean values of selected soil chemical properties in paddy fields during the study years.

\begin{tabular}{|c|c|c|c|c|c|c|c|c|}
\hline \multirow{2}{*}{ Year } & \multirow{2}{*}{$\mathrm{pH}$} & \multirow{2}{*}{$\mathrm{OM}$} & \multirow{2}{*}{ Avail. $\mathrm{P}_{2} \mathrm{O}_{5}$} & \multicolumn{3}{|c|}{ Exch. Cations } & \multirow{2}{*}{ Avail. $\mathrm{SiO}_{2}$} & \multirow{2}{*}{$\mathrm{CEC}$} \\
\hline & & & & $\mathrm{K}$ & $\mathrm{Ca}$ & $\mathrm{Mg}$ & & \\
\hline & $(1: 5)$ & $\mathrm{g} \mathrm{kg}^{-1}$ & $m g \mathrm{~kg}^{-1}$ & \multicolumn{3}{|c|}{ - - } & $\mathrm{mg} \mathrm{kg}^{-1}$ & $\mathrm{cmol}_{\mathrm{c}} \mathrm{kg}^{-1}$ \\
\hline 1999 & $\begin{array}{c}5.7 \mathrm{c}^{\dagger} \\
(4.6-8.9)^{\ddagger}\end{array}$ & $\begin{array}{c}23 b \\
(1-41)\end{array}$ & $\begin{array}{c}131 \mathrm{a} \\
(11-379)\end{array}$ & $\begin{array}{c}0.41 \mathrm{a} \\
(0.09-1.69)\end{array}$ & $\begin{array}{c}4.6 b c \\
(0.3-12.7)\end{array}$ & $\begin{array}{c}1.5 \mathrm{a} \\
(0.3-5.2)\end{array}$ & $\begin{array}{c}113 c \\
(35-445)\end{array}$ & - \\
\hline 2003 & $\begin{array}{c}5.8 \mathrm{ab} \\
(4.7-7.1)\end{array}$ & $\begin{array}{c}25 \mathrm{a} \\
(11-46)\end{array}$ & $\begin{array}{c}135 a \\
(32-483)\end{array}$ & $\begin{array}{c}0.37 b \\
(0.09-1.29)\end{array}$ & $\begin{array}{c}4.5 \mathrm{c} \\
(1.4-14.3)\end{array}$ & $\begin{array}{c}1.4 a \\
(0.4-3.5)\end{array}$ & $\begin{array}{c}128 b \\
(42-413)\end{array}$ & $\begin{array}{c}10.6 \mathrm{a} \\
(4.5-17.6)\end{array}$ \\
\hline 2007 & $\begin{array}{c}5.8 \mathrm{a} \\
(4.9-7.5)\end{array}$ & $\begin{array}{c}19 \mathrm{c} \\
(13-38)\end{array}$ & $\begin{array}{c}108 b \\
(6-800)\end{array}$ & $\begin{array}{c}0.34 b \\
(0.11-1.61)\end{array}$ & $\begin{array}{c}4.8 b \\
(1.3-11.0)\end{array}$ & $\begin{array}{c}1.4 \mathrm{a} \\
(0.3-3.9)\end{array}$ & $\begin{array}{c}142 \mathrm{a} \\
(5-1359)\end{array}$ & $\begin{array}{c}9.1 \mathrm{~b} \\
(3.4-17.0)\end{array}$ \\
\hline 2011 & $\begin{array}{c}5.7 b c \\
(4.7-7.1)\end{array}$ & $\begin{array}{c}22 c \\
(6-52)\end{array}$ & $\begin{array}{c}122 a \\
(14-944)\end{array}$ & $\begin{array}{c}0.24 \mathrm{c} \\
(0.05-0.93)\end{array}$ & $\begin{array}{c}5.2 \mathrm{a} \\
(1.4-14.3)\end{array}$ & $\begin{array}{c}1.5 \mathrm{a} \\
(0.3-3.5)\end{array}$ & $\begin{array}{c}119 b c \\
(22-548)\end{array}$ & $\begin{array}{c}10.3 \mathrm{a} \\
(3.4-18.9)\end{array}$ \\
\hline $\begin{array}{c}\text { Optimal } \\
\text { range }\end{array}$ & $5.5-6.5$ & $25-30$ & $80-120$ & $0.25-0.30$ & $5.0-6.0$ & $1.5-2.0$ & $157-180$ & $10-15$ \\
\hline
\end{tabular}

\footnotetext{
${ }^{\dagger}$ Numbers followed by the same letter within a column are not significantly different (Duncan test, $p<0.05$ ).
}

${ }^{\ddagger}$ Range of values determined in this study. 
2007. The concentrations of exchangeable $\mathrm{K}^{+}$were continuously declined from $0.41 \mathrm{cmol}_{\mathrm{c}} \mathrm{kg}^{-1}$ in 1999 to $0.24 \mathrm{cmol}_{\mathrm{c} \mathrm{kg}} \mathrm{kg}^{-1}$ in 2011. The decreases of available phosphorus and exchangeable $\mathrm{K}^{+}$might be also caused by the removal of rice straw from the paddy fields. Nonetheless, exchangeable $\mathrm{Ca}^{2+}$ concentrations in the paddy fields were tended to increase, and exchangeable $\mathrm{Mg}^{2+}$ was not changed during the study years.

The concentrations of available silicate gradually increased until $142 \mathrm{mg} \mathrm{kg}^{-1}$ in 2007 but then dropped down to $119 \mathrm{mg} \mathrm{kg}^{-1}$ in 2011. The available silicate concentrations were widely ranged between 5 and 1,359 $\mathrm{mg} \mathrm{kg}^{-1}$ depending upon the sampling sites. The variability of available silicate concentrations in the different paddy fields might be caused by farmer's avoidance to use silicate fertilizer supplied by Korean government because of the difficulties of its treatment and transport. Accordingly, agricultural scientists need to give the farms right and positive information about silicate fertilizer to enhance its application for improving soils of their paddy fields (Ahn et al., 2012). Exchangeable cation capacity (CEC) in the fields was only dropped down in 2007. It might be also come from decrease of SOM content caused by the rice straw removal. These results were also similar to the results of changes in soil chemical properties reported by NIAST (2008).

As comparing between optimal values of the selected soil chemical properties for rice cultivation and the values determined in this study, the soil $\mathrm{pH}$ values in the optimal range were from $53.0 \%$ to $81.7 \%$. SOM contents were between $9.7 \%$ and $29.3 \%$. Available phosphorus concentrations were from $19.0 \%$ to $44.3 \%$. Exchangeable $\mathrm{K}^{+}$concentrations were between $12.7 \%$ and $20.7 \%$. Available silicate concentrations in the range were from $4.7 \%$ to $9.3 \%$. In particular, the concentrations of available phosphorus were exceeded the range of optimal value, $80 \sim 120 \mathrm{mg} \mathrm{kg}^{-1}$, in many paddy fields. The paddy fields containing excess available phosphorus were between $30 \%$ and $53 \%$ during the study years. Thus, runoff water from the paddy fields containing excess available phosphorus would cause the eutrophication of streams and rivers (Cho et al., 2002; Lee et al., 2012).

Topographic distribution of paddy fields in Jeonbuk province, Korea was $43 \%$ local valley and fans, $39.3 \%$ fluvio-marine deposits, $15.0 \%$ alluvial plains, and $2.7 \%$ diluvial terraces (Kim, 2008). Figure 1 shows longterm investigation results of topographic effects on the changes in soil $\mathrm{pH}$ and SOM content in the paddy fields. Soil $\mathrm{pH}$ values ranged between 5.7 and 5.8 in all the topographic areas, which were statistically similar to a $\mathrm{pH}$ value, 5.7, reported by Sohn (1999).

The contents of SOM decreased in the paddy fields of diluvial terraces until 2007 and then increased in 2011, whereas the SOM contents in other topographic areas were up and down during the study years. In addition, the mean contents of SOM in the paddy fields of Jeonbuk province ranged between $22 \mathrm{~g} \mathrm{~kg}^{-1}$ and $25 \mathrm{~g} \mathrm{~kg}^{-1}$, which were lower than optimal contents $\left(25 \sim 30 \mathrm{~g} \mathrm{~kg}^{-1}\right)$. Also, the SOM contents were similar to $22 \sim 23 \mathrm{~g} \mathrm{~kg}^{-1}$ determined in paddy fields of Gyeongnam province (Lee et al., 2012).

The concentrations of available phosphorus in the paddy fields of local valley and fans, alluvial plains, and fluvio-marine plains were mostly declined during the study years. However, in the areas of diluvial terraces, the phosphorus concentrations gradually increased and were significantly higher than those in other topographic areas, especially from 2007. Ahn et
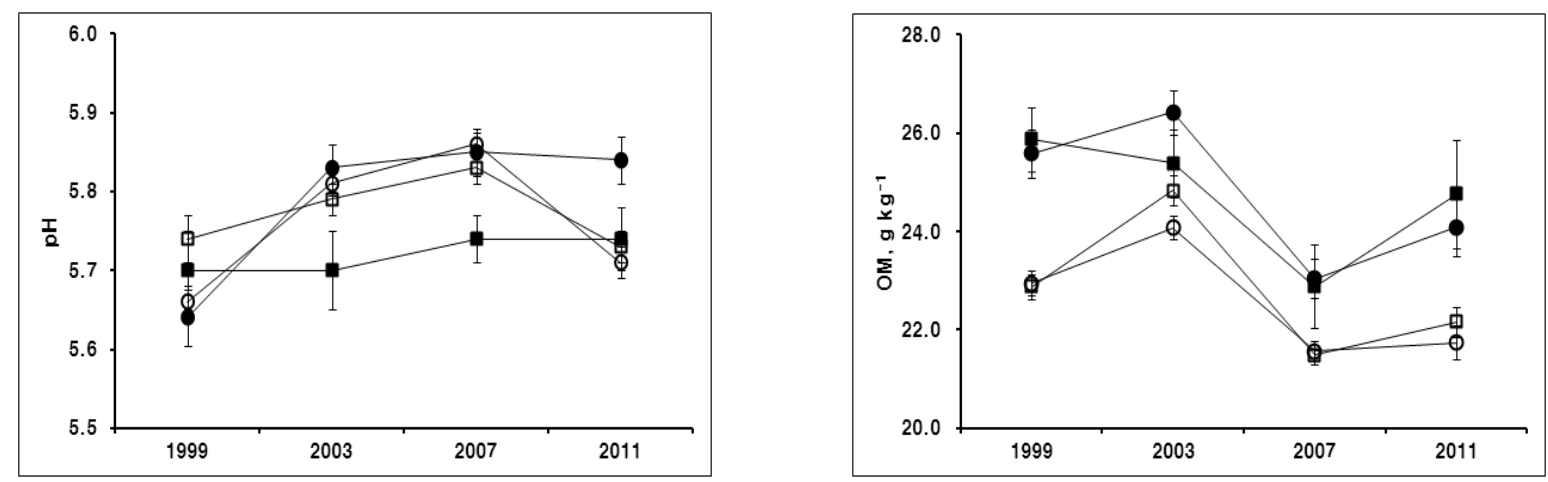

Fig. 1. Soil pH values and soil organic matter contents in the paddy fields as influenced by different topographic locations. $\bigcirc$, Local valley and fans; $O$, Alluvial plains; $\square$, Fluvio-marine plains; $\square$, Diluvial terrace. 

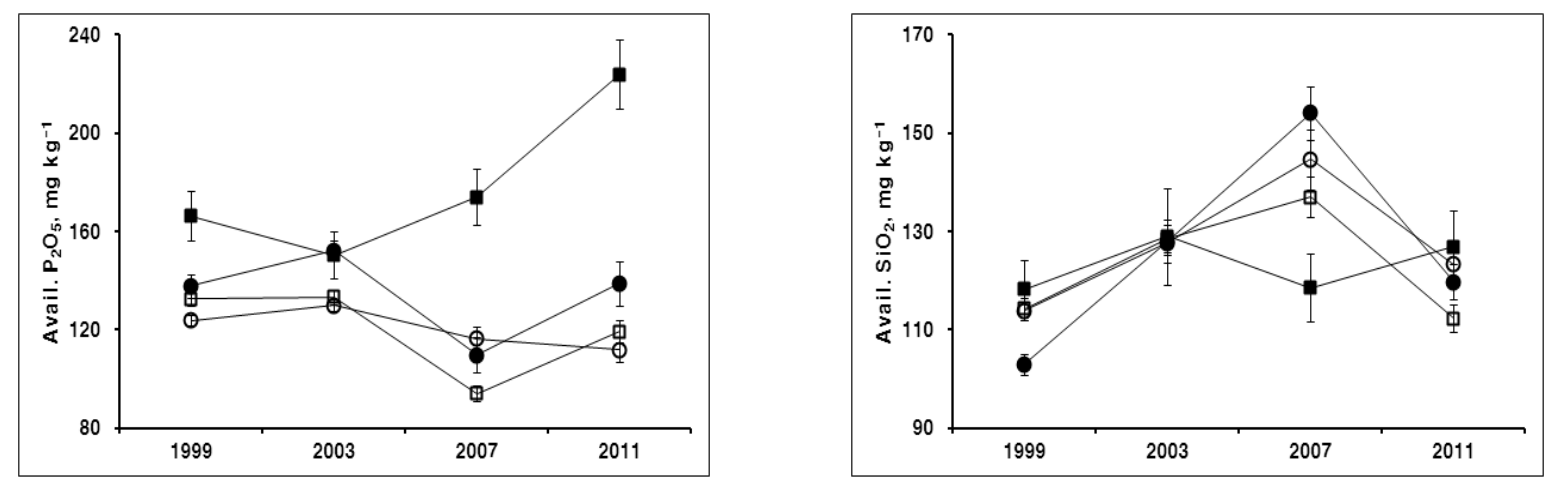

Fig. 2. The concentrations of available $\mathrm{P}_{2} \mathrm{O}_{5}$ and available $\mathrm{SiO}_{2}$ in the paddy fields as influenced by different topographic locations. $\bigcirc$, Local valley and fans; $\bigcirc$, Alluvial plains; $\square$, Fluvio-marine plains; $\square$, Diluvial terrace.
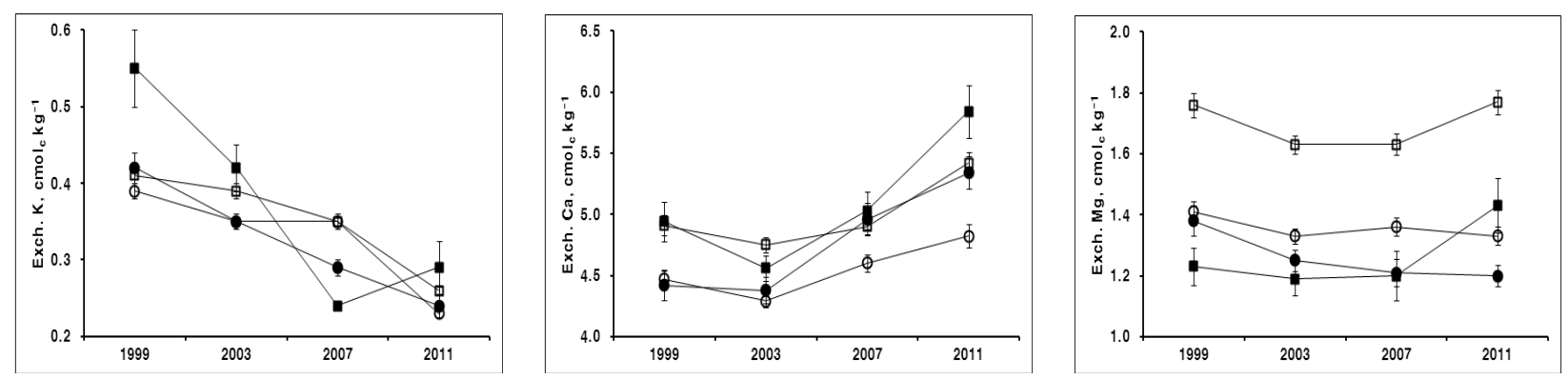

Fig. 3. The concentrations of exchangeable cations $\left(\mathrm{K}^{+}, \mathrm{Ca}^{2+}\right.$, and $\left.\mathrm{Mg}^{2+}\right)$ in the paddy fields as influenced by different topographic locations. $\bigcirc$, Local valley and fans; $\bigcirc$, Alluvial plains; $\square$, Fluvio-marine plains; $\square$, Diluvial terrace.

al. (2012) reported that the paddy fields of diluvial terrace areas were mainly comprised of immature soils which were mostly containing low SOM content and available phosphorus concentration (Fig. 2). Therefore, more precise topographical analysis might be necessary for the paddy fields. In contrast, the concentrations of available silicate increased in the areas of local valley and fans, alluvial plains, and fluvio-marine plains until 2007 and then dropped down, whereas the available silicate concentrations in diluvial terrace areas were not statistically changed (Fig. 2). At any rate, the average concentrations of available silicate in the paddy fields studied were lower than the optimal concentration range, $157 \sim 180 \mathrm{mg} \mathrm{kg}^{-1}$, so that the application of silicate fertilizer in the paddy fields will be needed to improve rice productivity and quality.

Changes in the concentrations of exchangeable cations, $\mathrm{K}^{+}, \mathrm{Ca}^{2+}$, and $\mathrm{Mg}^{2+}$, showed distinctly different trends among them during the study years (Fig. 3). The concentrations of exchangeable $\mathrm{K}^{+}$were gradually declined and then mostly reached the optimal range, $0.25 \sim 0.30 \mathrm{cmol}_{\mathrm{c}} \mathrm{kg}^{-1}$. The concentrations of $\mathrm{Ca}^{2+}$ increased from 2003 and made the optimal concentrations, $5.0 \sim 6.0 \mathrm{cmol}_{\mathrm{c}} \mathrm{kg}^{-1}$, in 2007, except in the areas of local valley and fans.

However, the concentrations of exchangeable $\mathrm{Mg}^{2+}$ were not changed during the study years. In particular, only the paddy fields of fluvio-marine plains contained $1.63 \sim 1.77 \mathrm{cmol}_{\mathrm{c}}$ of exchangeable $\mathrm{Mg}^{2+}$ in the optimal range, $1.5 \sim 2.0 \mathrm{cmol}_{\mathrm{c}} \mathrm{kg}^{-1}$, and other fields had lower exchangeable $\mathrm{Mg}^{2+}$ concentrations than its optimal range. Most of paddy fields in fluvio-marine plains contained high concentrations of exchangeable $\mathrm{Mg}^{2+}$ and $\mathrm{Na}^{+}$because the fields were influenced by intake of seawater (Ahn et al., 2012).

The mean concentrations of $0.1 \mathrm{M} \mathrm{HCl}$-extractable heavy metals, $\mathrm{Cd}, \mathrm{Cr}, \mathrm{Pb}, \mathrm{Cu}, \mathrm{Ni}$, and $\mathrm{Zn}$, in the paddy fields determined at four year intervals from 1999 are presented in Table 2. The concentrations of $\mathrm{Cd}, \mathrm{Cr}$, $\mathrm{Cu}, \mathrm{Ni}$, and $\mathrm{Zn}$ in the paddy fields were slightly and gradually declined during the study years, and the metal concentrations were the lowest in 2011. The concentrations of $\mathrm{Pb}$ were not statistically changed during the years.

The concentrations of each heavy metal determined were widely ranged during the investigation years: $\mathrm{Cd}$ concentrations ranged from 'not detectable (ND)' to $0.760 \mathrm{mg} \mathrm{kg}^{-1}$, the range of $\mathrm{Cr}$ concentrations was 
Table 2. Mean concentrations of $0.1 \mathrm{M} \mathrm{HCl}$-extractable heavy metals in paddy field during the study years.

\begin{tabular}{|c|c|c|c|c|c|c|}
\hline Year & $\mathrm{Cd}$ & $\mathrm{Cr}$ & $\mathrm{Pb}$ & $\mathrm{Cu}$ & $\mathrm{Ni}$ & $\mathrm{Zn}$ \\
\hline \multicolumn{7}{|c|}{ 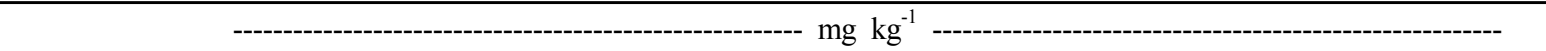 } \\
\hline 1999 & $\begin{array}{c}0.09 \mathrm{a}^{\dagger} \\
(0.003-0.760)^{\ddagger}\end{array}$ & $\begin{array}{c}0.22 \mathrm{a} \\
(0.002-1.950)\end{array}$ & $\begin{array}{c}4.97 \mathrm{a} \\
(0.29-47.36)\end{array}$ & $\begin{array}{c}4.66 \mathrm{a} \\
(0.14-15.12)\end{array}$ & $\begin{array}{c}0.52 \mathrm{~b} \\
(0.06-2.52)\end{array}$ & $\begin{array}{c}4.98 \mathrm{a} \\
(0.93-42.16)\end{array}$ \\
\hline 2003 & $\begin{array}{c}0.10 \mathrm{a} \\
(0.002-0.628)\end{array}$ & $\begin{array}{c}0.20 \mathrm{a} \\
(0.002-0.963)\end{array}$ & $\begin{array}{c}5.11 \mathrm{a} \\
(0.45-24.76)\end{array}$ & $\begin{array}{c}4.71 \mathrm{a} \\
(0.26-17.55)\end{array}$ & $\begin{array}{c}0.59 \mathrm{a} \\
(0.08-2.91)\end{array}$ & $\begin{array}{c}4.81 \mathrm{ab} \\
(1.03-25.58)\end{array}$ \\
\hline 2007 & $\begin{array}{c}0.07 \mathrm{~b} \\
(0.004-0.314)\end{array}$ & $\begin{array}{c}0.21 \mathrm{a} \\
(0.006-1.096)\end{array}$ & $\begin{array}{c}5.14 \mathrm{a} \\
(0.05-39.61)\end{array}$ & $\begin{array}{c}3.88 \mathrm{~b} \\
(0.01-19.15)\end{array}$ & $\begin{array}{c}0.59 \mathrm{a} \\
(0.04-3.70)\end{array}$ & $\begin{array}{c}4.26 \mathrm{~b} \\
(0.02-26.76)\end{array}$ \\
\hline 2011 & $\begin{array}{c}0.07 \mathrm{~b} \\
(\mathrm{ND}-0.590)\end{array}$ & $\begin{array}{c}0.14 \mathrm{~b} \\
(\mathrm{ND}-0.860)\end{array}$ & $\begin{array}{c}4.87 \mathrm{a} \\
(0.01-47.96)\end{array}$ & $\begin{array}{c}2.94 \mathrm{c} \\
(0.01-20.62)\end{array}$ & $\begin{array}{c}0.47 b \\
(0.01-2.69)\end{array}$ & $\begin{array}{c}2.32 \mathrm{c} \\
(0.01-13.48)\end{array}$ \\
\hline
\end{tabular}

${ }^{\dagger}$ Numbers followed by the same letter within a column are not significantly different (Duncan test, $p<0.05$ ).

${ }^{\ddagger}$ Range of metal concentrations determined in this study; ND: not detectable.

from $\mathrm{ND}$ to $1.950 \mathrm{mg} \mathrm{kg}^{-1}, \mathrm{~Pb}$ concentrations were from $0.01 \mathrm{mg} \mathrm{kg}^{-1}$ to $47.96 \mathrm{mg} \mathrm{kg}^{-1}, \mathrm{Cu}$ concentrations were from $0.01 \mathrm{mg} \mathrm{kg}^{-1}$ to $20.62 \mathrm{mg} \mathrm{kg}^{-1}$, Ni concentrations were from $0.01 \mathrm{mg} \mathrm{kg}^{-1}$ to $3.70 \mathrm{mg} \mathrm{kg}^{-1}$, and $\mathrm{Zn}$ concentrations ranged between $0.01 \mathrm{mg} \mathrm{kg}^{-1}$ and $42.16 \mathrm{mg} \mathrm{kg}^{-1}$. However, the concentrations of heavy metals in the paddy fields determined in this study were significantly lower than the levels of Soil Contamination Warning Standard (SCWS; $5 \mathrm{mg} \mathrm{Cr}$ $\mathrm{kg}^{-1}, 4 \mathrm{mg} \mathrm{Cd} \mathrm{kg}{ }^{-1}, 200 \mathrm{mg} \mathrm{Pb} \mathrm{kg}{ }^{-1}, 150 \mathrm{mg} \mathrm{Cu} \mathrm{kg}$, $100 \mathrm{mg} \mathrm{Ni} \mathrm{kg}{ }^{-1}, 300 \mathrm{mg} \mathrm{Zn} \mathrm{kg}{ }^{-1}$ ) for agricultural lands (1-region) presented in Soil Environment Conservation Law (SECL) established by Ministry of Environment (MOE), Korea (2012). Therefore, the paddy fields in Jeonbuk province, Korea would be very safe from the heavy metal contaminations.

\section{Conclusions}

Long-term investigations of selected soil chemical properties and heavy metal, $\mathrm{Cd}, \mathrm{Cr}, \mathrm{Pb}, \mathrm{Cu}, \mathrm{Ni}$, and $\mathrm{Zn}$ concentrations in the paddy field soils of different topographic areas were conducted at four year intervals from 1999 to 2011. Soil $\mathrm{pH}$ values were within optimal range for rice cultivation. The contents of soil organic matter (SOM) significantly decreased in 2007 due to rice straw removal from the fields. The concentrations of available phosphorus were only reduced in 2007. The concentrations of exchangeable $\mathrm{K}^{+}$were continuously declined during the study years. The concentrations of available silicate gradually increased in 2007 but then dropped down in 2011. In particular, the available silicate concentrations were widely ranged between 5 and $1359 \mathrm{mg} \mathrm{kg}^{-1}$ depending upon the sampling sites, which might be caused by farmer's avoidance to use silicate fertilizer because of the difficulties of its treatment and transport. Exchangeable cation capacity (CEC) was only dropped down in 2007 because it might be also come from the rice straw removal. As comparing with optimal values of the selected soil chemical properties for rice cultivation, the mean concentrations of available phosphorus were exceeded the range of optimal value, $80 \sim 120 \mathrm{mg} \mathrm{kg}^{-1}$, in many paddy fields, whereas the mean values of other properties were lower or close to the optimal values. Soil $\mathrm{pH}$ values ranged between 5.7 and 5.8 in all the topographic areas. The concentrations of available phosphorus in the paddy fields of local valley and fans, alluvial plains, and fluvio-marine plains were mostly declined, except in diluvial terrace areas. Unexpectedly, the phosphorus concentrations in the fields of diluvial terrace areas gradually increased and were significantly higher than others. On the other hand, the concentrations of available silicate increased in most topographic areas until 2007 and then dropped down, except in diluvial terrace areas. The concentrations of exchangeable $\mathrm{K}^{+}$were gradually declined and then mostly reached the optimal range. The concentrations of $\mathrm{Ca}^{2+}$ increased from 2003 and made the optimal concentrations in 2007, except in the areas of local valley and fans. The paddy fields of fluvio-marine plains only contained in the optimal range of exchangeable $\mathrm{Mg}^{2+}$ concentrations, but other fields had lower than its optimal range.

The mean concentrations of $0.1 \mathrm{M} \mathrm{HCl}$-extractable heavy metals, $\mathrm{Cd}, \mathrm{Cr}, \mathrm{Pb}, \mathrm{Cu}, \mathrm{Ni}$, and $\mathrm{Zn}$, in the paddy fields were slightly and gradually declined during the study years, but the $\mathrm{Pb}$ concentrations were not 
statistically changed. In addition, the concentrations of heavy metals were widely ranged due to the sampling sites as $\mathrm{ND} \sim 0.760 \mathrm{mg} \mathrm{Cd} \mathrm{kg}{ }^{-1}, \mathrm{ND} \sim 1.950 \mathrm{mg} \mathrm{Cr}$ $\mathrm{kg}^{-1}, 0.01 \sim 47.96 \mathrm{mg} \mathrm{Pb} \mathrm{kg}{ }^{-1}, 0.01 \sim 20.62 \mathrm{mg} \mathrm{Cu} \mathrm{kg}^{-1}$, $0.01 \sim 3.70 \mathrm{mg} \mathrm{Ni} \mathrm{kg}{ }^{-1}$, and $0.01 \sim 42.16 \mathrm{mg} \mathrm{Zn} \mathrm{kg}^{-1}$. However, the concentrations of heavy metals determined in this study were significantly lower than the levels of SCWS for agricultural lands (1-region) presented in SECL.

\section{Acknowledgements}

This research was supported by Rural Development Administration (PJ006906162011), Korea.

\section{References}

Ahn, B.K., J.H. Lee, K.C. Kim, H.G. Kim, S.S. Jeong, H.W. Jeon, and Y.S. Zhang. 2012. Changes in chemical properties of paddy soils as influenced by regional topography in Jeonbuk province. Korean J. Soil Sci. Fert. 45(3):393-398.

Cho, J.Y., K.W. Han, J.K. Choi, Y.J. Kim, and K.S. Yoon. 2002. $\mathrm{N}$ and $\mathrm{P}$ losses from a paddy field plot in central Korea. Soil Sci. Plant Nutr. 48:301-306.

Hyeon, K.S., C.S. Park, S.J. Jung, and J. Moon. 1989. Physico-chemical properties of soils developed on the different topographies in Korea. Korean J. Soc. Soil Sci. Fert. 22:271-279.

Jeollabuk-Do. 2007. Statistics system for status of Jeonbuk provincial government. Jeonbuk, (in Korea)

Jung, S.J. and T.S. Kim. 1988. Topographic characteristics, formation and classification of soils developed in limestone. Konkuk University Master's Thesis.

Kim, S.K. 2008. Soil science. Greentomato, Seoul.

Lee, Y.H., Y.K. Sonn, S.T. Lee, J.Y. Heo, M.K. Kim, E.S. Kim, W.D. Song, Y.S. Zhang, W.T. Jeon, and Y.S. Oh. 2012. Topographical chemical properties of paddy soils in Gyeongnam province. Korean J. Soil Sci. Fert. 45(2):143-148.

MOE (Ministry of Environment). 2012. Enforcement decree of the soil environment conservation act. Ministry of Environment, Korea.

NIAST (National Institute of Agricultural Science and Technology). 2008. Annual report of the monitoring project on agro-environmental quality in 2007. NIAST, Rural Development Administration, Korea.

NIAST (National Institute of Agricultural Science and Technology). 2000. Method of soil and plant analysis. NIAST, Rural Development Administration, Korea.

NIAST (National Institute of Agricultural Science and Technology). 2010. Method of soil and plant analysis. NIAST, Rural Development Administration, Korea.

Sohn, B.K., J.S. Cho, J.G. Kang, J.Y. Cho, K.Y. Kim, H.W. Kim, and H.L. Kim. 1999. Physico-chemical properties of soils at red pepper, garlic and onion cultivation ares in Korea. Korean. J. Soc. Soil Sci. Fert. 32:123-131. 